\title{
Small intestinal plasma cells in coeliac disease
}

\author{
B B SCOTT, ANNE GOODALL, P STEPHENSON, AND D JENKINS
}

From the Departments of Medicine and Pathology, Lincoln County Hospital, Lincoln

SUMMARY Using a modified immunoperoxidase technique to achieve optimum staining and reproducible counts of plasma cells in paraffin embedded tissue, IgA, IgM, IgE, and IgG plasma cells were studied in small bowel biopsies from 20 controls, 23 untreated coeliac patients, 19 treated coeliac patients, and seven patients with Crohn's disease not involving duodenum or jejunum. In controls the ratio of the mean counts for $\operatorname{IgA}, \operatorname{IgM}, \operatorname{IgE}$, and $\operatorname{IgG}$ plasma cells was $2 \cdot 5: 1: 1: 1$ respectively. In patients with untreated coeliac disease, counts of all types of plasma cell were significantly increased approximately two-fold compared with controls although for IgG cells there was considerable overlap. The ratio of the mean plasma cell counts in the untreated coeliac patients was $3 \cdot 5: 1 \cdot 5: 2: 1$. Counts fell significantly after treatment with a gluten-free diet. There was no significant difference between counts in the controls and the Crohn's disease patients. The changes found in coeliac disease may simply be a non-specific response to mucosal damage. The increases in $\operatorname{IgA}$ and IgM plasma cells, however, suggest that the deposits of extracellular IgA and IgM observed in coeliac mucosa are locally produced, and the increase in IgE plasma cells raises the possibility that reaginic type hypersensitivity may be involved in coeliac disease.

The small intestinal mucosal damage in coeliac disease is caused by an abnormal response to the gluten fraction of wheat and certain other cereals. The mechanism of the damage is not known but immunological factors are thought to play an important part. Both cell mediated and humoral responses, which are by no means mutually exclusive, have been incriminated. We have previously shown that there are deposits of $\operatorname{IgA}$ and complement in the lamina propria and basement membrane zone of untreated but not of treated adult coeliac patients. ${ }^{1}$ Other studies have shown deposits of IgA by 24 hours $^{2}$ and three months ${ }^{3}$ after gluten challenge of treated coeliac patients. One study showed deposits of IgM and complement during the first 12 hours after gluten challenge. ${ }^{4}$ These results suggest that a local antigen-antibody reaction (possibly gluten and gluten antibody) with complement activation may be responsible for mucosal damage. It seems likely that the extracellular immunoglobulin shown in those studies was locally produced. In support of this it has been shown that coeliac jejunal mucosa cultured in vitro

Address for correspondence: Dr B B Scott, Lincoln County Hospital, Sewell Road, Lincoln LN2 5OY.

Received for publication 11 March 1983 in the presence of gluten produces both $\operatorname{IgA}$ and IgM gliadin antibody. ${ }^{5}$ One might therefore expect to find an increase in the concentration of $\operatorname{IgA}$, and possibly IgM, plasma cells in the mucosa of untreated coeliac patients with a fall to normal following treatment. Unfortunately the results of different studies of mucosal plasma cells in coeliac disease are very conflicting, no two studies agreeing. $^{3-9}$ Furthermore, even the studies of mucosal plasma cells in control subjects vary greatly - the ratio of $\operatorname{IgA}: \operatorname{IgG}$ plasma cells varying from $3: 1$ to $30: 1 .^{68-12}$ This confliction may be explained partly by the small numbers of subjects studied - six to 13 for coeliac patients and six to 17 for controls. Probably of more importance are problems of technique. In most studies immunofluorescence has been used. Although this may be the best method for showing extracellular immunoglobulin it is unsatisfactory for accurately counting plasma cells because it is difficult to distinguish extracellular from intracellular staining and it is difficult to recognise the type of cell in which positive staining is found. Immunoperoxidase staining is much more satisfactory as the morphology of the cells can be well seen and miscounting of plasma cell is less likely. Furthermore, as paraffin sections are used, routine histology can be done as well. Even with the 
immunoperoxidase method, however, we have shown that results are misleading unless each antiserum is titrated with each specimen so that counting is done at a plateau level of staining. ${ }^{13}$ IgE plasma cells have received little attention. This may be because initial studies ${ }^{11} 14$ found few or no IgE plasma cells in intestinal mucosa and it was concluded that IgE mechanisms were not involved. ${ }^{14}$ Subsequent studies have suggested that IgE plasma cells are available for participation in local reaginic type reactions in the intestine $e^{1516}$ and that they might be involved in coeliac disease. ${ }^{17} 18$

In view of these considerations we felt it important to re-investigate plasma cells, especially IgE plasma cells, in coeliac disease, both before and after treatment with a gluten free diet, using larger numbers of patients and controls and an immunoperoxidase technique in which each specimen is individually titrated with antiserum.

\section{Methods}

\section{PATIENTS}

\section{CONTROL GROUP}

Twenty patients with the irritable bowel syndrome who after investigation for abdominal pain and/or diarrhoea were found to have no organic gastrointestinal disease. The mean age was 41 years (range 12-77 years) and eight were male.

\section{UNTREATED COELIAC GROUP}

Twenty three patients with subtotal or severe partial villous atrophy and crypt hyperplasia. All except two were rebiopsied after treatment with a gluten free diet and these all showed unequivocal histological improvement. Three also had dermatitis herpetiformis and 10 were also in the treated coeliac group. The mean age was 44 years (range 13-77 years) and six were male.

\section{TREATED COELIAC GROUP}

Nineteen patients who had had a small bowel biopsy showing subtotal or severe partial villous atrophy and crypt hyperplasia before treatment and an unequivocal histological improvement after treatment with a gluten free diet. The duration of treatment at the time of study varied from four months to 10 years (mean two years). Nine had biopsies which were almost completely normal, the rest showing partial villous atrophy. Three also had dermatitis herpetiformis. The mean age was 43 years (range 15-76 years) and seven were male.

CROHN'S DISEASE GROUP

Seven patients acting as a further control group.
They all had radiological or histological evidence of Crohn's disease but no sign of involvement of the duodenum or jejunum. Routine histology of the small bowel biopsies was completely normal. The mean age was 43 years (range 18-77 years) and three were male.

SMALL INTESTINAL BIOPSY

Biopsies were taken during the course of routine management with the hydraulic multiple biopsy instrument, orientated on plastic mesh and fixed in formalin as previously described. ${ }^{19}$

\section{STAINING TECHNIQUES}

The fixed specimens were embedded into paraplast. Tissue sections were cut at $1 \mu$ thickness perpendicular to the luminal surface, mounted on glass slides and dried overnight at $37^{\circ} \mathrm{C}$. Sections were stained for $\operatorname{IgA}$, IgM, IgE, and IgG by the PAP immunoperoxidase technique ${ }^{20}$ after initial trypsinisation, ${ }^{1}$ and counterstained with Harris haematoxylin for the morphometric study. Rabbit anti-human immunoglobulin heavy chain antisera, together with swine anti-rabbit antiserum, and peroxidase-rabbit anti-peroxidase complex were obtained from Dakopatts. Specificity of the primary antisera was confirmed by immunoelectrophoresis and by testing against human monoclonal myeloma cases. Particular care was taken to standardise the anti-IgE antiserum using positive and negative substrates in view of the reported high incidence of cross reactivity with IgA. ${ }^{22}$ We used a single batch of anti-IgE antiserum for the whole study and no cross reactivity was detected with this batch on control sections. Titration of primary antisera in the range $1: 50$ to $1: 32000$ showed that at high dilutions the count of immunoglobulin containing cells fell with decreasing titre. In the intermediate range consistent cell counts could be shown graphically to lie on a plateau. At high concentration non-specific staining made identification of cellular immunoglobulin very inaccurate. For these reasons cell counts were made within the plateau range. This was found to vary from case to case and the titration was therefore performed for each case to obtain the plateau count.

\section{MEASUREMENTS}

Measurements and cell counts on the immunoperoxidase stained sections were carried out using a MOPPET image analyser. An image of the stained sections was projected at standard magnification on to the digitising tablet by a Leitz Neopromar projection microscope. The MOP stylus was fitted with a ball point pen to provide a permanent record of the field examined. Four contiguous, non- 
overlapping fields were examined on each section. A field was defined as the area between the mucosal surface and muscularis mucosae bounded by two lines perpendicular to the muscularis mucosae. The following three measurements were made on each field: (1) mucosal length - the length of the muscularis mucosae; (2) area of lamina propria; and (3) immunoglobulin containing cell counts. A micrometer slide was used to convert area and length measurements on the projected image into absolute measurement. For each section cell counts were expressed as cells $/ \mathrm{mm}$ mucosal length and as cells/ $\mathrm{mm}^{2}$ lamina propria area. All measurements and processing were performed blind on randomised specimens to minimise experimental and observer bias.

\section{STATISTICAL METHODS}

Immunoglobulin containing cell counts in each disease group were compared with those of the control group and each other group using the Student's $t$ test with Bessel's correction for small samples and log transformation.

\section{Results}

The results were similar whether the counts were expressed as cells per $\mathrm{mm}^{2}$ of lamina propria or per millimetre mucosal length and for convenience we have presented all the results just as cells per millimetre mucosal length. This is the 'areal density' which permits valid comparisons between control and damaged coeliac mucosa. ${ }^{23}$ The plasma cell counts are shown in Figs 1-4. The mean counts for IgA, IgM, IgE, and IgG plasma cells in controls were $323,137,156$, and 133 respectively giving a ratio of approximately $2 \cdot 5: 1: 1: 1$. The mean counts in the untreated coeliac group were $755,349,379$, and 213 respectively giving a ratio of approximately $3 \cdot 5: 1 \cdot 5: 2: 1$. The counts of $\operatorname{IgA}, \operatorname{IgM}$, and $\operatorname{IgE}$ plasma cells were very significantly greater in the untreated coeliacs than in controls $(p<0 \cdot 001)$. For IgG the difference was less significant $(p<0.01)$ and there was considerable overlap. There was no significant difference between the treated coeliacs and the controls except for $\operatorname{IgA}(\mathrm{p}<0.01)$ and the difference between treated and untreated coeliacs was significant $(p<0.001)$ for all plasma types except IgG. The counts in the patients with dermatitis herpetiformis were not dissimilar to the counts in the other coeliac patients. There was no significant correlation between the initial plasma cell counts and the histological response to the gluten free diet. In the treated coeliacs all the plasma cell counts correlated positively with the degree of remaining villous abnormality. There was no significant

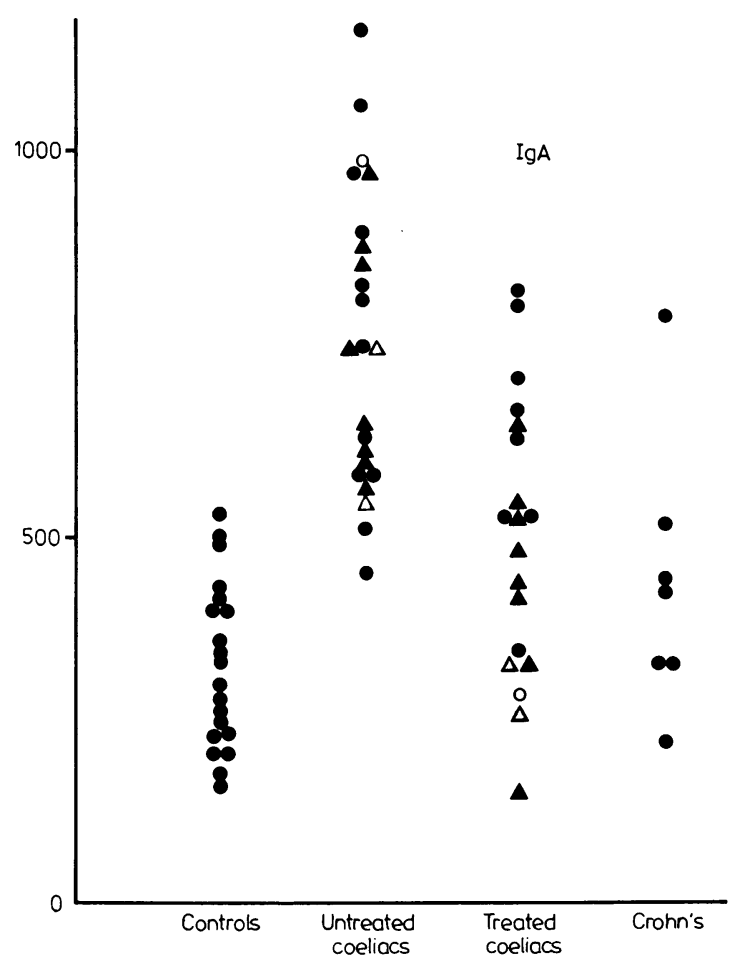

Fig. 1 IgA plasma cell counts per mm mucosal length. Open circles and triangles represent patients with dermatitis herpetiformis. Triangles represent patients studied both before and after treatment with gluten free diet.

difference between the counts in the controls and the Crohn's disease group.

\section{Discussion}

We have confirmed that $\operatorname{IgA}$ plasma cells predominate in small intestinal mucosa although the predominance is very much less than that found in most other studies using smaller numbers and less satisfactory techniques. Our findings in the small bowel are similar to those in the rectum ${ }^{13}$ except that IgG cell counts are greater by a factor of four in the small bowel. In untreated coeliac disease there is approximately a two-fold increase in all the plasma cells with a return towards normal after treatment.

The increase in $\operatorname{IgA}$ and IgM plasma cells in untreated coeliac disease is compatible with the suggestion that the deposits of extracellular $\operatorname{IgA}$ and IgM observed in coeliacs ${ }^{1-4}$ are locally produced.

The increase in IgE plasma cells suggests that reaginic type hypersensitivity may be involved in coeliac disease - a possibility which has received 


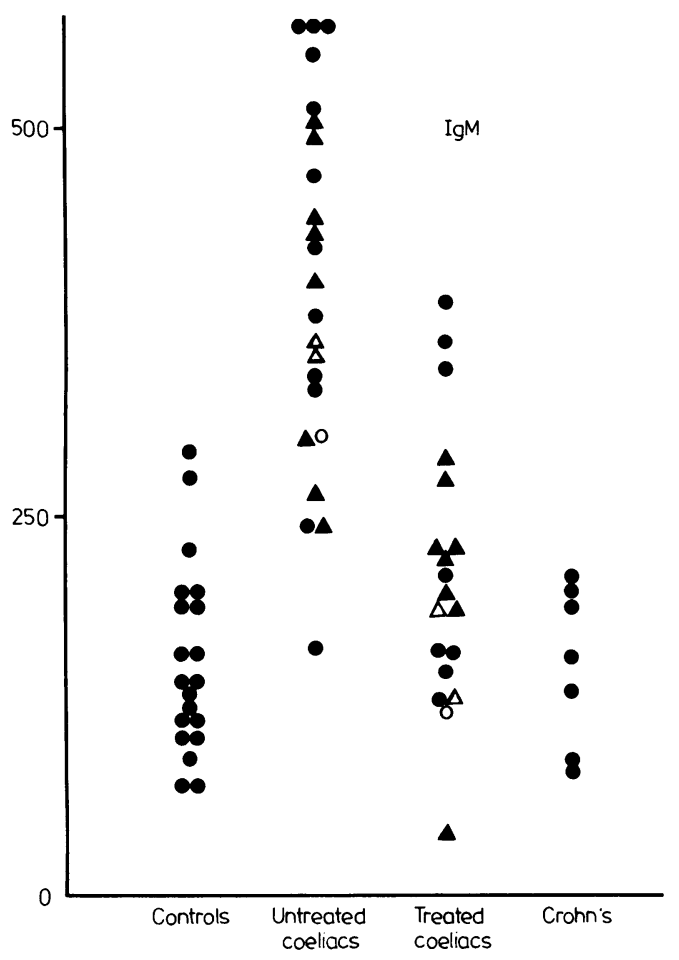

Fig. 2 IgM plasma cell counts per $\mathrm{mm}$ mucosal length. Open circles and triangles represent patients with dermatitis herpetiformis. Triangles represent patients studied both before and after treatment with gluten free diet.

little attention. In support of such a mechanism, Shiner found in an ultrastructural study ${ }^{18}$ of childhood coeliac disease that oedema of the lamina propria, vascular changes, cisternal dilatation of plasma cells, and mast cell degranulation together with a moderate increase in eosinophils and polymorphs occurred within a few hours after gluten challenge and preceded any epithelial abnormality or infiltration of lymphocytes. Furthermore, Kumar and colleagues ${ }^{17}$ found increased IgE plasma cells, using an immunofluorescent technique, and increased mast cell counts in untreated coeliacs. We, however, have previously reported no significant increase in lamina propria mast cells in 11 untreated coeliacs, ${ }^{24}$ but both studies can be criticised because only granulated mast cells were sought. The occasional association between coeliac disease and systemic mast cell disease ${ }^{24}$ might also suggest the involvement of reaginic type hypersensitivity in coeliac disease. The reliability of immunofluorescent staining for showing IgE plasma cells in the gut mucosa has been criticised on the grounds of

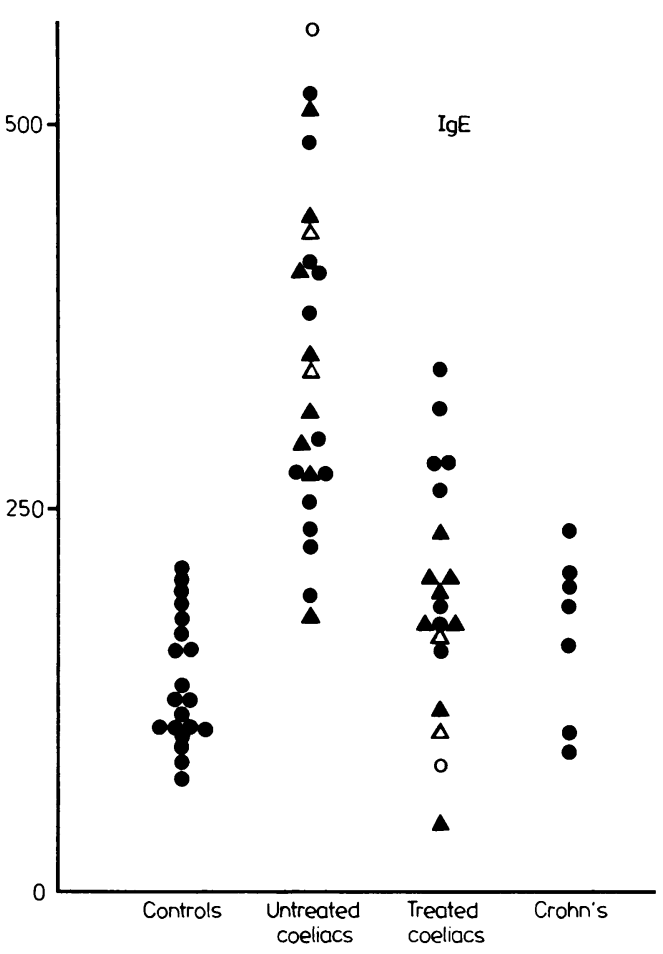

Fig. 3 IgE plasma cell counts per mm mucosal length. Open circles and triangles represent patients with dermatitis herpetiformis. Triangles represent patients studied both before and after treatment with gluten free diet.

non-specific staining of eosinophilic granulocytes by fluorescein conjugated proteins, ${ }^{25}$ and confusion with mast cells containing IgE. ${ }^{26}$ The use of an immunoperoxidase technique in our study allows accurate recognition of eosinophils, basophils, typical mast cells, and typical plasma cells. It is difficult in single sections, however, to distinguish with certainty some plasma cells from degranulated mast cells. If reaginic type hypersensitivity is involved in coeliac disease it may be linked to subsequent immune complex deposition and cell mediated immunity - for which there is already a lot of evidence - as it has been postulated ${ }^{16}$ that the leak produced by local allergy in the intestine may be important as a necessary prerequisite for accumulation of enough antigen to precipitate local Arthus type and cell mediated immune reactions.

Notwithstanding these suggestions the increase of the plasma cells may simply be a non-specific effect of mucosal damage by analogy with the findings in the rectal mucosa of patients with inflammatory bowel disease and with bacterial colitis. ${ }^{13}$ 


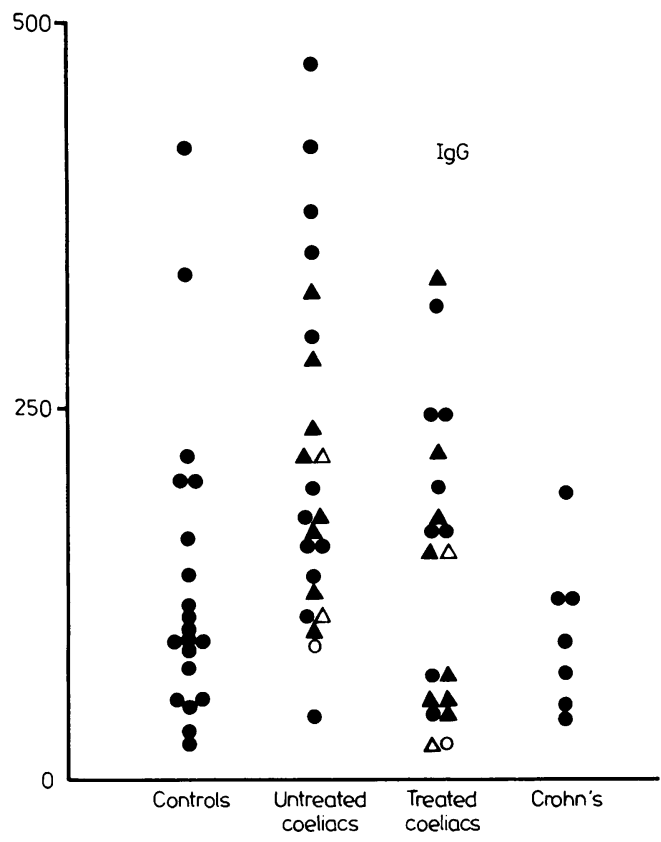

Fig. 4 IgG plasma cell counts per mm mucosal length. Open circles and triangles represent patients with dermatitis herpetiformis. Triangles represent patients studied both before and after treatment with gluten free diet.

The normal findings in the patients with Crohn's disease lend no support to the suggestion that plasma cells are increased in the apparently uninvolved bowel of patients with Crohn' disease. ${ }^{27}$

We thank Professors I M P Dawson and M S Losowsky for their helpful advice, and Mrs Joan Arden for secretarial assistance. We thank the Trent Regional Health Authority Research Committee for generous financial support.

\section{References}

1 Scott BB, Scott DG, Losowsky MS. Jejunal mucosal immunoglobulins and complement in untreated coeliac disease. J Pathol 1977; 121: 219-23.

2 Shiner $\mathbf{M}$, Ballard $\mathrm{J}$. Antigen-antibody reactions in jejunal mucosa in childhood coeliac disease after gluten challenge. Lancet 1972; 1: 1202-5.

3 Lancaster-Smith M, Packer S, Kumar PJ, Harries JT. Immunological phenomena in the jejunum and serum after reintroduction of dietary gluten in children with treated coeliac disease. J Clin Pathol 1976; 29: 592-7.

4 Doe WF, Henry K, Booth CC. Complement in coeliac disease. In: Hekkens WThJM, Pena AS, eds. Coeliac disease. Leiden: Stenfert Kroese, 1974: 189-94.

5 Falchuk ZM, Strober W. Gluten-sensitive enteropathy: synthesis of antigliadin antibody in vitro. Gut 1974; 15: 947-52.

6 Soltoft J. Immunoglobulin-containing cells in nontropical sprue. Clin Exp Immunol 1970; 6: 413-20.

7 Douglas AP, Crabbé PA, Hobbs JR. Immunochemical studies of the serum, intestinal secretions and intestinal mucosa in patients with adult celiac disease and other forms of the celiac syndrome. Gastroenterology 1970; 59: 414-25.

8 Pettingale $\mathrm{KW}$. Immunoglobulin-containing cells in the coeliac syndrome. Gut 1971; 12: 291-6.

9 Baklien K, Brandtzaeg P, Fausa O. Immunoglobulins in jejunal mucosa and serum from patients with adult coeliac disease. Scand J Gastroenterol 1977; 12: 149-59.

10 Crabbé PA, Heremans JF. The distribution of immunoglobulin-containing cells along the human gastrointestinal tract. Gastroenterology 1966; 51: 30516.

11 Savilahti E. Immunoglobulin-containing cells in the intestinal mucosa and immunoglobulins in the intestinal juice in children. Clin Exp Immunol 1972; 11: 415-25.

12 Van Spreeuwel JP, Lindeman J, Van Der Wal AM et al. Morphological and immunohistochemical findings in upper gastrointestinal biopsies of patients with Crohn's disease of the ileum and colon. J Clin Pathol 1982; 35: 934-40.

13 Scott BB, Goodall A, Stephenson P, Jenkins D. Rectal mucosal plasma cells in inflammatory bowel disease. Gut 1983; 24: 519-24.

14 Hobbs JR, Hepner GW, Douglas AP, Crabbé PA, Johansson SGO. Immunological mystery of coeliac disease. Lancet 1969; 2: 649-50.

15 Brown WR, Borthistle BK, Chen ST. Immunoglobulin $\mathrm{E}$ and IgE-containing cells in human gastrointestinal fluids and tissues. Clin Exp Immunol 1975; 20: 227-37.

16 Editorial. Allergy in the gastrointestinal tract. Lancet 1975; 2: 1021-3.

17 Kumar P, O'Donoghue DP, Lancaster-Smith $M$. Cellular changes in the jejunal mucosa following the reintroduction of gluten in treated coeliac disease. In: Pepys J, Edwards AM, eds. The mast cell - its role in health and disease. Tunbridge Wells: Pitman Medical, 1979: 647-50.

18 Shiner $M$. Ultrastructural features of allergic manifestations in the small intestine of children. Scand J Gastroenterol 1981; 16: suppl 70: 49-64.

19 Scott BB, Losowsky MS. Peroral small-intestinal biopsy: experience with the hydraulic multiple biopsy instrument in routine clinical practice. Gut 1976; 17: 740-3.

20 Taylor CR. Immunoperoxidase techniques. Arch Pathol Lab Med 1978; 102: 113-21.

21 Curran RC, Gregory J. The unmasking of antigens in paraffin sections by trypsin. Experientia (Basle) 1977; 33: $1400-1$.

22 Piris J, Murdoch DL. Immunoglobulin E in ulcerative 
colitis and non-specific proctitis - studies with a monoclonal antibody. [Abstract.] Gut 1981; 22: A875-6.

23 Marsh MN. Studies of intestinal lymphoid tissue. Gastroenterology 1980; 79: 481-92.

24 Scott BB, Hardy GJ, Losowsky MS. Involvement of the small intestine in systemic mast cell disease. Gut 1975; 16: 918-24.

25 Brandtzaeg $\mathrm{P}$, Baklien $\mathrm{K}$. Inconclusive immunohistochemistry of human IgE in mucosal pathology. Lancet
1976; 1: 1297-8.

26 Mayrhofer G, Bazin H, Gowans JL. Nature of cells binding anti-IgE in rats immunized with Nippostrongylus brasiliensis: IgE synthesis in regional nodes and concentration in mucosal mast cells. Eur $J$ Immunol 1976; 6: 537-45.

27 Ferguson R, Allan RN, Cook WT. A study of the cellular infiltrate of the proximal jejunal mucosa in ulcerative colitis and Crohn's disease. Gut 1975; 16: 205-8. 